\title{
Levels of defoliation and regrowth dynamics in elephant grass swards
}

\section{Níveis de desfolhação e a dinâmica da rebrotação em pastos de capim-elefante}

\author{
Giselle Regina Rodolfo ${ }^{\mathrm{I}}$ Daniel Schmitt ${ }^{\mathrm{I}}$ \\ Kamila Maciel Dias' ${ }^{\mathrm{I}}$ André Fischer Sbrissia ${ }^{{ }^{*}}$
}

\section{ABSTRACT}

\begin{abstract}
The morphogenetic and structural characteristics of forage plants and the processes of growth and senescence in tissues may vary according to the grazing management strategies used. This research aimed to assess the process of regrowth in elephant grass swards $c v$. 'Pioneiro'submitted to two pre-grazing heights $(90$ and $120 \mathrm{~cm})$ combined with two levels of defoliation (50 and $70 \%)$. A reduction of the leaf elongation rate (LER) was observed during the regrowth stages, in addition to a reduction in the rate of leaf appearance (LAR) and aerial tiller population density (ATPD). In contrast, an increase was observed in leaf senescence (LSR) and stem and pseudo stem elongation rates (SER). The severe defoliation (70\%) combined with a pre-grazing height of $120 \mathrm{~cm}$ compromised the regrowth of elephant grass $\mathrm{cv}$. 'Pioneiro', which must be managed with a maximum height of $90 \mathrm{~cm}$ and maximum level of defoliation of $50 \%$ of the initial height.
\end{abstract}

Key words: morphogenesis, regrowth stages, Pennisetum purpureum, grazing management, pioneiro-grass.

\section{RESUMO}

As características morfogênicas e estruturais das plantas forrageiras, bem como os processos de crescimento e senescência de tecidos podem variar de acordo com as estratégias de manejo utilizadas. O objetivo deste trabalho foi avaliar o processo de rebrotação em pastos de capim-elefante, cultivar 'Pioneiro', submetidos a duas alturas em pré-pastejo (90 e $120 \mathrm{~cm})$ combinadas com duas severidades de desfolhação (50 e 70\% da altura inicial). Ao longo das fases de rebrotação, ocorreu uma diminuição das taxas de alongamento foliar (TAF), aparecimento de folhas (TAP) e da densidade populacional de perfilhos aéreos (DPPA), aumento das taxas de senescência foliares (TSF) e alongamento de colmo mais pseudocolmo (TACP). A severidade de desfolha de $70 \%$ aliada à altura em pré-pastejo de $120 \mathrm{~cm}$ comprometeu o processo de rebrotação do capim-elefante cv. 'Pioneiro', devendo este ser manejado com altura máxima de $90 \mathrm{~cm}$ e com severidade de desfolha não excedendo $50 \%$ da altura inicial.

Palavras-chave: morfogênese, fases de rebrotação, Pennisetum purpureum, manejo do pastejo, capim-pioneiro.

\section{INTRODUCTION}

Among the different tropical climate forage grasses, elephant grass is one of the most important species, as it is grown across almost every tropical and subtropical region and has a high potential for dry matter production (PEREIRA et al., 2010). Regarding its management, recent studies that used the critical leaf area index (LAI) as the maximum threshold for interruption of regrowth suggested that the leaf production is optimal at heights of approximately $85 \mathrm{~cm}$ for the 'Napier' (PEREIRA et al., 2014) and $100 \mathrm{~cm}$ for the 'Cameroon' (VOLTOLINI et al., 2010) cultivars, respectively.

Elephant grass is a caespitose plant, and some types of this grass produce a large amount of aerial tillers. In the 'Napier' cultivar, CARVALHO et al. (2007) observed that the aerial tillers were responsible for approximately $75 \%$ of the LAI of swards in summer. Moreover, according to the same authors, the responses of basal and aerial tiller classes in elephant grass under grazing can vary widely according to grazing management practices.

'Programa de Pós-graduação em Ciência Animal, Centro de Ciências Agroveterinárias, Universidade do Estado de Santa Catarina (UDESC), Avenida Camões, 2090, 88520-000, Lages, SC, Brasil. E-mail: andre.sbrissia@udesc.br. "Corresponding author. 
Some studies have shown that the ideal time to interrupt grazing must not exceed $50 \%$ of the initial height because beyond this point, there is a reduction in the instantaneous herbage intake rate (FONSECA et al., 2012) with a possible negative impact on herbage intake and animal performance. Studies with aruana guinea grass and annual ryegrass conducted by ZANINI et al. (2012) indicated that approximately $90 \%$ of the stem mass is concentrated in the first half of the sward, suggesting that the presence of this component could act as a physical barrier to grazing animals.

Thus, the aim of this research was to evaluate the regrowth patterns of elephant grass swards cv. 'Pioneiro' submitted to two pre-grazing heights (90 and $120 \mathrm{~cm}$ ) combined with two levels of defoliation (50 and 70\%).

\section{MATERIAL AND METHODS}

The experiment was conducted in Lages, Santa Catarina, between January and June 2011. The experimental area is classified as clay-humic aluminum leptic cambisol (EMBRAPA, 2006) and presented the following chemical features in the 0-20cm layer: $\mathrm{pH}$ in $\mathrm{H}_{2} \mathrm{O}=5.3 ; \%$ organic matter $=$ 3.8; $\mathrm{P}=9.8$ (Mehlich-1) and $\mathrm{K}=137 \mathrm{mg} \mathrm{dm}^{-3} ; \mathrm{Ca}=3.8$,
$\mathrm{Mg}=1.7, \mathrm{Al}=0.8$, cation-exchange capacity $=6.6$ and $\mathrm{H}+\mathrm{Al}=10.5$, cmolc $\mathrm{dm}^{-3}$; sum of bases $=35.8 \%$. The Meteorological Station of the Agricultural Research and Rural Extension Company (EPAGRI) of Lages/ SC provided weather data during the experimental period (Figure 1).

The experimental area was composed of 12 paddocks, each with an area of approximately $600 \mathrm{~m}^{2}$, established since February 2010 with elephant grass (Pennisetum purpureum Schumach cv. 'Pioneiro'). In January 2011, the whole experimental area was fertilized with urea at $50 \mathrm{~kg} \mathrm{~N} / \mathrm{ha}$. Upon reaching the pre-grazing height, the pastures were lowered to the residual height targets and the height was standardized by manual mowing before the first grazing cycle with the aim of ensuring that the initial end points of residual heights were properly created. During the pasture growing season (January to June 2011) a total of $250 \mathrm{~kg} \mathrm{~N} \mathrm{ha}^{-1}$ was applied in split applications throughout the season. Because the grazing interval was not constant, the total amount of $\mathrm{N}$ to be applied was divided by the number of days of growing season and a daily rate calculated. The amount of $\mathrm{N}$ in each application was adjusted according to the length of the rest period of each experimental unit.

A randomized block design with three replications was used according to a $2 \times 2$ factorial

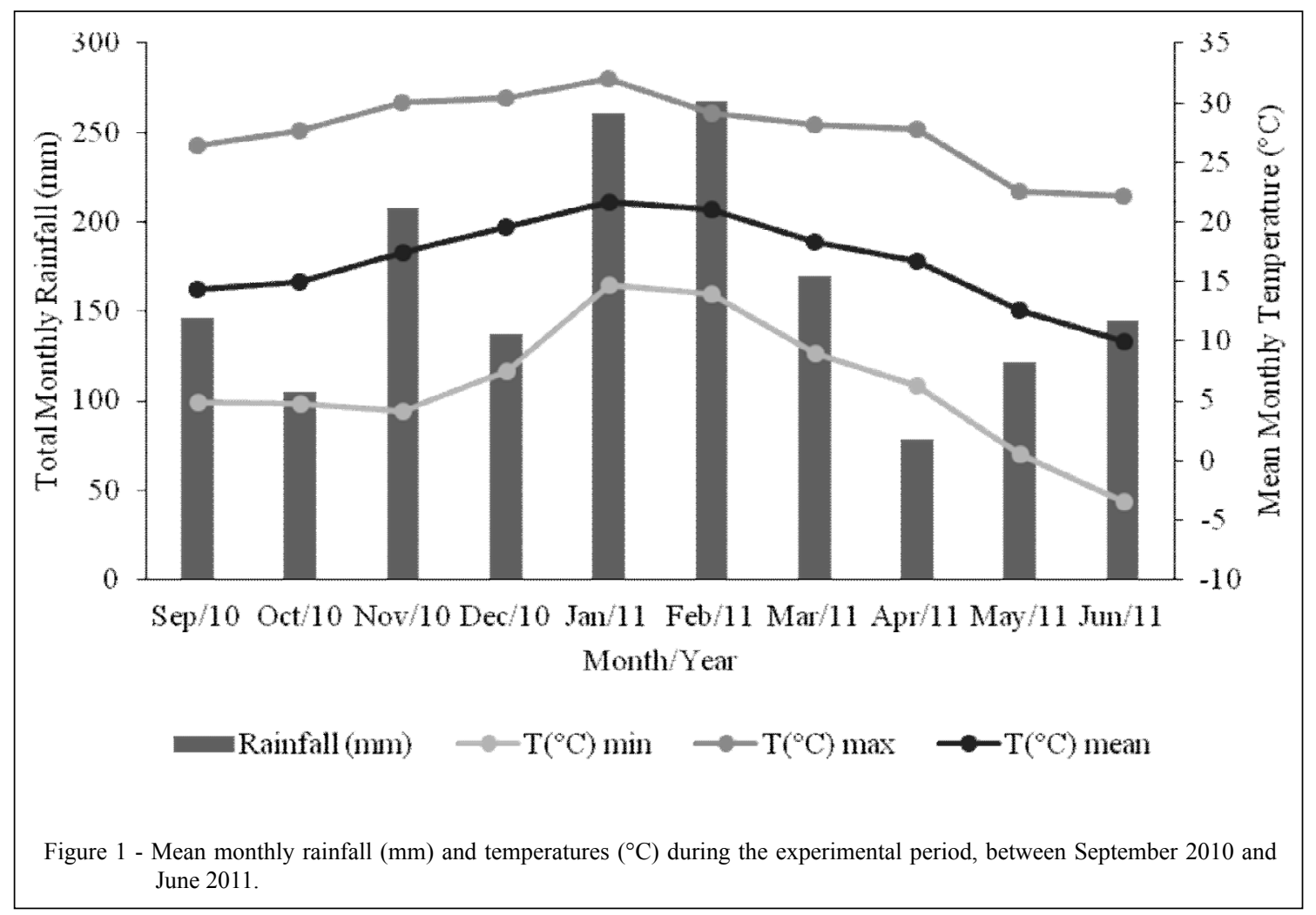

Ciência Rural, v.45, n.7, jul, 2015. 
arrangement, which consisted of the combination of two pre-grazing heights (90 and $120 \mathrm{~cm})$ and two levels of defoliation (removal of 50 or $70 \%$ of the initial pre-grazing height), resulting in four treatments: $90 / 50,90 / 70,120 / 50$ and $120 / 70$ that generated different residual post-grazing heights (45, 27,60 and $36 \mathrm{~cm}$, respectively). The initial idea was to determine the optimal pre-grazing height target for elephant grass cv. 'Pioneiro' based on critical leaf area index (LAI) concept (around 95\% of light interception). However, the available equipment to measure light intensity requires sunny days to perform reliable estimates and, unfortunately, there were very long sequences of cloudy days in the beginning of the experiment that prevented it could be used such values to estimate optimal pre-grazing height for this cultivar. Therefore, pre-grazing height targets were defined as an average of preliminary results observed by PEREIRA et al. (2014) with elephant grass cv. 'Napier' and VOLTOLINI et al. (2010) with elephant grass cv. 'Cameroon', which found optimal heights for leaf production of 85 and $100 \mathrm{~cm}$ for these cultivars, respectively. The $120 \mathrm{~cm}$ height was defined to create a contrasting management scenario widely used by local farmers. Similarly, based on the research of ZANINI et al. (2012) and FONSECA et al. (2012), the levels of defoliation used, of 50 and $70 \%$, were chosen to create contrasting conditions of low and high harvest efficiency, respectively. Before grazing, samples of herbage mass were collected at ground level in three quadrats of $1 \mathrm{~m}^{2}$ each to calculate the stocking rate necessary to graze the pastures down to the desired residue targets. The occupation period was calculated to the last two days based on a total herbage intake of $2.5 \%$ of body weight. Pastures were grazed by heifers (average body weight of $320 \mathrm{~kg}$ ) and lactating cows (average body weight of $550 \mathrm{~kg}$ ).

The sward height was monitored weekly with a sward stick at 60 random points per experimental unit. All assessments were conducted during the regrowth stages, where each "stage" where pre-defined as the sward height corresponding to each third of the canopy height and was obtained by subtracting the residual height from the pre-grazing target height of each treatment and dividing by three. The tillers were marked at points that represented the average condition (height) of the sward and were selected 20 tillers per experimental unit at a proportion of 12 aerial and 8 basal tillers (considering a proportion of $60 / 40 \%$ of aerial/basal tillers from observations collected prior to the beginning of the experiment). Tissue flow measurements always began at post-grazing, and new tillers were selected at each new grazing cycle. The tiller population density at each experimental unit was determined at pre-grazing in three representative points in $1 \mathrm{~m}^{2}$ quadrats, and the basal and aerial tillers were counted separately.

The leaf elongation (LER), appearance (LAR), senescence (LSR), and stem and pseudo stem elongation rates (SER) together with the number of green leaves (NFL) and expanding leaves (NEL), average length of stem and pseudo stem (ALSP), and basal and aerial tiller population density (BTPD and ATPD) were calculated from the field data.

For analysis, the data were arranged in cycles. Once pooled, they were analyzed by using the MIXED procedures of the SAS (Statistical Analysis System) statistical package. The average values for the treatments were estimated using LSMEANS, and comparisons were performed through the PDIFF procedure using Tukey's test at a 5\% significance level.

\section{RESULTS AND DISCUSSION}

The experimental period included two grazing seasons, summer and autumn. Because it was not the main objective of this study to detect possible variations between the seasons, the grazing cycles were pooled and considered as repeated measurements. However, it should be emphasized that there were 3 grazing cycles for the $90 / 50,120 / 50$ and $90 / 70$ pastures and two grazing cycles for $120 / 70$ treatment. The relative low number of grazing cycles and, consequently, a large interval between grazing can be attributed to the mild weather conditions, with averages mean temperatures decreasing from March (Figure 1).

The greater values for leaf elongation rate (LER) were observed in swards grazed with $50 \%$ defoliation $\left(3.22 \mathrm{~cm}\right.$ tiller $^{-1}$ day $^{-1}$ vs. $2.37 \mathrm{~cm}$ tiller $^{-1}$ day $^{-1}$ in swards submitted to $70 \%$ defoliation) and it was reduced throughout the stages of regrowth, with average values of $3.03 \mathrm{~cm}$ tiller- 1 day $^{-1}$ at the first and second stages and a value of $2.39 \mathrm{~cm}^{-1}$ tiller- 1 day $^{-1}$ at the third stage (final stage of regrowth). These values are 3 to 4 times lower than those observed by PEREIRA et al. (2013) studying elephant grass cv. 'Napier' and this can be attributed to cultivar difference but also to mild summer/autumn temperatures during the entire experiment period. Swards grazed at $90 \mathrm{~cm}$ presented relatively constant leaf senescence rates (LSR) throughout regrowth, but swards grazed at $120 \mathrm{~cm}$ presented higher values at the final stage with the same pattern of response being observed for $50 \%$ and $70 \%$ defoliation (Table 1).

Swards grazed at $120 \mathrm{~cm}$ presented higher values for stem elongation rates (SER) than 
Table 1 - Leaf senescence (LSR), stem and pseudo stem elongation (SER), and leaf appearance (LAR) rates (cm tiller ${ }^{-1} \mathrm{day}^{-1}$ ) in elephant grass cv. 'Pioneiro' swards grazed at two pre-grazing heights $(\mathrm{cm})$ and two severities of defoliation (\%) during the regrowth stages.

\begin{tabular}{|c|c|c|c|c|c|c|c|c|}
\hline \multirow[b]{2}{*}{ Regrowth stages } & \multicolumn{2}{|c|}{---Pre-grazing height---- } & \multicolumn{2}{|c|}{-----Level of defoliation---- } & \multicolumn{2}{|c|}{-------Pre-grazing height------ } & \multicolumn{2}{|c|}{------Pre-grazing height------ } \\
\hline & 90 & 120 & 50 & 70 & 90 & 120 & 90 & 120 \\
\hline Initial & $1.71 \mathrm{Aa}$ & $2.07 \mathrm{Ba}$ & $1.96 \mathrm{Aa}$ & $1.83 \mathrm{Ba}$ & $1.13 \mathrm{Aa}$ & $1.20 \mathrm{Ba}$ & $0.22 \mathrm{Aa}$ & $0.26 \mathrm{Aa}$ \\
\hline Intermediate & $1.80 \mathrm{Aa}$ & $2.08 \mathrm{Ba}$ & $1.98 \mathrm{Aa}$ & $1.90 \mathrm{Aba}$ & $1.75 \mathrm{Aa}$ & $2.39 \mathrm{Aa}$ & $0.19 \mathrm{Aa}$ & $0.14 \mathrm{Ba}$ \\
\hline Final & $1.45 \mathrm{Ab}$ & $2.90 \mathrm{Aa}$ & $1.71 \mathrm{Ab}$ & $2.64 \mathrm{Aa}$ & $1.16 \mathrm{Ab}$ & $2.64 \mathrm{Aa}$ & $0.12 \mathrm{Ba}$ & $0.13 \mathrm{Ba}$ \\
\hline
\end{tabular}

Similar letters in uppercase in columns and lowercase in rows, for the same variable, are not different, according to Tukey's test at $5 \%$.

$90 \mathrm{~cm}$ swards (Table 1), and this effect was more pronounced at the second and third regrowth phases. Leaf appearance rates (LAR) was reduced throughout the regrowth stages and presented higher values at $50 \%$ defoliation (on average, 0.20 leaves tiller ${ }^{-1}$ day $^{-1}$ ) than at defoliation of $70 \%$ ( 0.15 leaves tiller 1 day $\left.^{-1}\right)$. Immediately after a defoliation event, the sheath length is normally very short; therefore, emerging leaves are more quickly exposed to light, enabling higher LERs at the early stages of regrowth. In tropical forage plants, the stem fraction is important for growth, as it has strong influence on canopy structure and competition for light (FAGUNDES et al., 2006). This was clear in this experiment, where it was observed a decrease in LER and an increase in SER and ALSP during the regrowth stages (Table 1).

Swards submitted to more severe grazing present higher proportions of sheaths than leaves lamina. These structures, according to PARSONS et al. (1983), contribute to less than $5 \%$ of the canopy photosynthesis, which can result in lower LER. An opposite condition must have occurred in pastures with $50 \%$ defoliation, which were allowed to keep a larger leaf area after grazing. Additionally, newly grown and growing leaves have a higher photosynthetic efficiency than mature or senescent leaves, accounting for approximately $75 \%$ of the plant's photosynthesis (PARSONS, et al., 1988).

A study carried out in Dactylis glomerata indicated a decrease in LAR associated with an increase in sheath lenght (DURU \& DUCROCQ, 2000), and a similar response was found in this experiment, as with the decrease in LER and increase in ALSP, the leaves had more time to grow, which led to a reduction in LAR. Additionally noteworthy was the reduction in LAR in swards grazed at $120 \mathrm{~cm}$ (Table 1), at the intermediate stage of regrowth, combined with high LSR, which pushed the potential NGL to the plant limit in this stage of regrowth.

The highest LSR at the final stage, particularly in $120 \mathrm{~cm}$ swards with $70 \%$ defoliation, may be attributed to the fact that plants in this condition took longer to reach the final height, which induced an intra-tussock environment with more shade. The decrease in LER associated with an increase in LSR shows that the leaf growth and senescence events occurred simultaneously and antagonistically, and that an environment more favorable to harvesting was already present at the intermediate stage of regrowth, regardless of the pre-grazing height.

Until the intermediate stage of regrowth, the NGL was similar for the two pre-grazing heights of 90 and $120 \mathrm{~cm}$, increasing in both cases at the last third of regrowth. At the final stage, the NGL was higher for swards grazed at $90 \mathrm{~cm}$. The average length of the stem and pseudo stem (ALSP) was similar for pastures with pre-grazing heights of 90 and $120 \mathrm{~cm}$ at the initial stage of regrowth. However, the ALSP increased across the stages and was higher in swards grazed at $120 \mathrm{~cm}$ (Table 2).

Throughout the regrowth stages, a higher basal tiller population density (BTPD) was observed in swards grazed at $120 \mathrm{~cm}$ with $70 \%$ defoliation. The ATPD increased during re-growth in pastures grazed with $50 \%$ defoliation. In contrast, it decreased during the regrowth phases in pastures submitted to $70 \%$ defoliation (Table 3). Regarding total tiller population density (TTPD), 293 tillers $\mathrm{m}^{-2}$ were observed at the first stage of regrowth, followed by a significant increase and the highest values at the second stage (420 tillers $\mathrm{m}^{-2}$ ), and a decrease at the third stage (331 tillers $\mathrm{m}^{-2}$ ), with no differences among treatments.

In Brachiaria brizantha swards, SOUSA et al. (2011) showed that higher defoliation severity 
Table 2 - Number of green leaves (NGL) (leaves tiller ${ }^{-1}$ ) and average length of stem and pseudo stem (ALSP) (cm) in elephant grass Cv. 'Pionero' swards grazed at two pre-grazing heights $(\mathrm{cm})$ during the regrowth stages.

\begin{tabular}{|c|c|c|c|c|}
\hline Regrowth stages & NGL & ALSP & NFL & ALSP \\
\hline Initial & $7.0 \mathrm{~B} \mathrm{a}$ & $25.33 \mathrm{C} \mathrm{a}$ & $7.4 \mathrm{~B} \mathrm{a}$ & $30.42 \mathrm{C} \mathrm{a}$ \\
\hline Intermediate & $8.5 \mathrm{~A} \mathrm{a}$ & $31.58 \mathrm{~B} \mathrm{~b}$ & $8.2 \mathrm{~A} \mathrm{a}$ & $41.24 \mathrm{~B} \mathrm{a}$ \\
\hline Final & $8.8 \mathrm{~A} \mathrm{a}$ & $38.17 \mathrm{~A} \mathrm{~b}$ & $7.8 \mathrm{AB} b$ & $57.81 \mathrm{~A} \mathrm{a}$ \\
\hline
\end{tabular}

Similar letters in uppercase in columns and lowercase in rows, for the same variable, are not different, according to Tukey's test at $5 \%$.

resulted in the removal of a larger proportion of the forage, enabling the appearance of new tillers. Similarly, in this experiment, after the $70 \%$ of defoliation there was a higher incidence of light in the tussocks, which caused an increase in BTPD. As the regrowth process advanced, no differences were found in the BTPD of swards grazed with $50 \%$ defoliation because the grass may have already reached its tillering threshold at the initial stage of regrowth. Additionally, swards submitted to $70 \%$ defoliation took longer to produce new leaves and therefore did not present all of their tillering capacity in the first third of regrowth, reaching this threshold at the intermediate stage.

The ATPD increase may be attributed to the increase in leaf area, the amount of photo assimilates produced, and the development of potential tiller-producing locations, i.e., so-called "site filling" (DAVIES, 1974). The ATPD decrease at the final stage of sward regrowth combined with $70 \%$ defoliation may be attributed to the elevation of the apical meristem and the apical dominance, inhibiting the aerial tillering, in addition to the increase in SER and ALSP, where the assimilates are destined to these processes and less prioritized to aerial tillering.

Finally, it should be emphasized that residue height targets were successfully achieved for the level of defoliation of $50 \%(50,48$ and $49 \%$ for $90 / 50$ treatment; 47,45 and $43 \%$ for $120 / 50$ treatment) but animals had difficulties to graze down pastures at $70 \%$ of defoliation $(66,57$ and $52 \%$ for $90 / 70$ treatment at first, second and third grazing cycle respectively and 71 and $48 \%$ for $120 / 70$ treatment at first and second grazing cycle, respectively), despite of the insistence to keep animals into the paddocks to graze down pastures at this level of defoliation. This results indicate that grazing severity of $70 \%$ it is not possible to be achieved for this tussock forming species and any insistence to doing so will be harmful for both; grazing animals and plants, since the great pressure to remove practically all pasture leaf area will probably negatively impact animal performance and plant regrowth process.

\section{CONCLUSION}

The results suggest that level of defoliation must not exceed $50 \%$ of the initial pre-grazing height in elephant grass swards cv. 'Pioneiro'. However, the hypothesis of whether this cultivar could be managed with pre-grazing heights lower than $90 \mathrm{~cm}$ must still be tested.

Table 3 - Basal and aerial tiller population density (tiller $\mathrm{m}^{-2}$ ) of elephant grass cv. 'Pioneiro' swards grazed at two pre-grazing heights (cm) and two severities of defoliation (\%) during the regrowth stages.

\begin{tabular}{|c|c|c|c|c|c|c|}
\hline \multirow[b]{2}{*}{ Regrowth stages } & \multicolumn{4}{|c|}{----Pre-grazing height $(\mathrm{cm})---------$ Level of defoliation $(\%)----$} & \multicolumn{2}{|c|}{-------Level of Defoliation (\%)------- } \\
\hline & 90 & 120 & 50 & 70 & 50 & 70 \\
\hline Initial & $65 \mathrm{~B} \mathrm{a}$ & $44 \mathrm{~B}$ a & $43 \mathrm{~A} \mathrm{a}$ & $67 \mathrm{~B} \mathrm{a}$ & $190 \mathrm{~B} \mathrm{a}$ & $239 \mathrm{~B} \mathrm{a}$ \\
\hline Intermediate & $89 \mathrm{~A} \mathrm{a}$ & $75 \mathrm{~A} \mathrm{a}$ & $47 \mathrm{~A} \mathrm{~b}$ & $117 \mathrm{~A} \mathrm{a}$ & $279 \mathrm{~A} \mathrm{a}$ & $335 \mathrm{~A} \mathrm{a}$ \\
\hline Final & $68 \mathrm{~B} \mathrm{~b}$ & $98 \mathrm{~A} \mathrm{a}$ & $60 \mathrm{~A} \mathrm{~b}$ & $105 \mathrm{~A} \mathrm{a}$ & $273 \mathrm{AB}$ a & $182 \mathrm{~B} \mathrm{~b}$ \\
\hline
\end{tabular}

Similar letters in uppercase in columns and in lowercase in rows, for the same variable, are not different, according to Tukey's test at $5 \%$. 


\section{ACKNOWLEDGEMENTS}

We thank Coordenação de Aperfeiçoamento de Pessoal de Nível Superior (CAPES) for the scholarship and Conselho Nacional de Pesquisa e Desenvolvimento Tecnológico $(\mathrm{CNPq})$ for funding this research (Grant number: 483533/2011-4)

\section{REFERENCES}

CARVALHO, C.A.B. et al. Classes de perfilhos na composição do índice de área foliar em pastos de capim-elefante. Pesquisa Agropecuária Brasileira, v.42, n.4, p.557-563, 2007. Available from: <http://dx.doi.org/10.1590/S0100204X2007000400014>. Accessed: jan. 28, 2015. doi: 10.1590/ S0100-204X2007000400014.

DAVIES, A. Leaf tissue remaining after cutting and regrowth in perennial ryegrass. Journal of Agricultural Science, v. 82, n. 1, p.165-172, 1974. Available from: <http://dx.doi.org/10.1017/ S0021859600050334>. Accessed: jan. 28, 2015. doi: 10.1017/ S0021859600050334.

DURU, M.; DUCROCQ, H. Growth and senescence of the successive grass leaves on a tiller. Ontogenic development and effect of temperature. Annals of Botany, v.85, n. 5, p.635-643, 2000. Available from: <http://dx.doi.org/10.1006/anbo.2000.1116>. Accessed: jan. 28, 2015. doi: 10.1006/anbo.1999.1117.

EMBRAPA (EMPRESA BRASILEIRA DE PESQUISA AGROPECUÁRIA). Sistema brasileiro de classificação de solos. 2. ed. Rio de Janeiro: EMBRAPA-SPI, 2006. 306p.

FAGUNDES, J.L. et al. Características morfogênicas e estruturais do capim-braquiária em pastagem adubada com nitrogênio avaliadas nas quatro estações do ano. Revista Brasileira de Zootecnia, v.35, n.1, p.21-29, 2006. Available from: <http:// dx.doi.org/10.1590/S1516-35982006000100003>. Accessed: jan. 28, 2015. doi: 10.1590/S1516-35982006000100003.

FONSECA, L. et al. Management targets for maximizing the shortterm herbage intake rate of cattle grazing in Sorghum bicolor. Livestock Science, v.145, n.1-3, p.205-211, 2012. Available from: $<$ http://dx.doi.org/10.1016/j.livsci.2012.02.003 $>$. Accessed: jan. 28, 2015. doi: 10.1016/j.livsci.2012.02.003.

JONES, M.B.; LAZENBY, A. The grass crop: the physiological basis of production. London: Chapman \& Hall, 1988. 369p.
PARSONS, A.J. et al. Leaf age structure and canopy photosynthesis in rotationally and continuously grazed swards. Grass and Forage Science, v.43, n.1, p.1-14, 1988. Available from: <http:// dx.doi.org/10.1111/j.1365-2494.1988.tb02136.x>. Accessed: jan. 28, 2015. doi: 10.111/j.1365-2494.1988.tb02136.x.

PARSONS, A.J. et al. The physiology of grass production under grazing. 1. Characteristics of leaf and canopy photosynthesis of continuously grazed swards. Journal of Applied Ecology, v.20, n.1, p.117-126, 1983. Available from: <http://dx.doi. org/10.2307/2403380>. Accessed: jan. 28, 2015. doi: $10.2307 / 2403380$

PEREIRA, A.V. et al. Pennisetum purpureum. In: FONSECA, D.M. da; MARTUSCELLO, J.A. (Eds.). Plantas forrageiras. Viçosa: UFV, 2010. p.197-219.

PEREIRA, L.E.T. et al. Regrowth patterns of elephant grass (Pennisetum purpureum Schum) subjected to strategies of intermitente stocking management. Grass and Forage Science, v. 70, n.1, p. 195-204, 2015. Available from: <http://dx.doi.org/10.1111/ gfs.12103>. Accessed: jan. 28, 2015. doi: 10.1111/gfs.12103.

PEREIRA, L.E.T. et al. Grazing management and tussock distribution in elephant grass. Grass and Forage Science, 2014. Online version of record published before inclusion in an issue. Available from: <http://dx.doi.org/10.1111/gfs.12137>. Accessed: jan. 28, 2015. doi: 10.1111/gfs. 12137 .

SOUSA, B.M.L. et al. Morphogenetic and structural characteristics of xaraes palisadegrass submitted to cutting heights. Revista Brasileira de Zootecnia, v.40, n.1, p.53-59, 2011. Available from: $\quad<$ http://dx.doi.org/10.1590/S1516-35982011000100008>. Accessed: jan. 28, 2015. doi: 10.1590/S1516-35982011000100008.

VOLTOLINI, T.V. et al. Características produtivas e qualitativas do capim-elefante pastejado em intervalo fixo ou variável de acordo com a interceptação da radiação fotossinteticamente ativa. Revista Brasileira de Zootecnia, v.39, n.5, p.10021010, 2010. Available from: <http://dx.doi.org/10.1590/S151635982010000500009>. Accessed: jan. 28, 2015. doi: 10.1590/ S1516-35982011000100008.

ZANINI, G.D. et al. Distribuição de colmo na estrutura vertical de pastos de capim Aruana e azevém anual submetidos a pastejo intermitente por ovinos. Ciência Rural, v.42, n.5, p.882-887, 2012. Available from: <http://www.scielo.br/pdf/cr/v42n5/ a13612cr4299.pdf $>$. Accessed: jan. 28, 2015. doi: 10.1590/S010384782012000500020 . 